\title{
Technical efficiency of Boro rice production in Bangladesh: A case of bio-slurry application
}

\author{
H. Kabir ${ }^{1^{*}}$, M. Musharraf ${ }^{2}$, M. M. Haque ${ }^{3}$ and M. Khan ${ }^{4}$ \\ ${ }^{1}$ Department of Agricultural Economics, Bangladesh Agricultural University, Mymensingh-2202, ${ }^{2}$ Department of \\ Economics, Jatiya Kabi Kazi Nazrul Islam University, Trishal, Mymensingh, ${ }^{3}$ Graduate Training Institute, Bangladesh \\ Agricultural University, Mymensingh-2202 and ${ }^{4}$ Department of Animal Science, Bangladesh Agricultural University, \\ Mymensingh-2202, Bangladesh, *E-mail: hkabir75@yahoo.com
}

\begin{abstract}
The main objective of this study is to estimate the impact of bioslurry to Boro rice production in Bangladesh. Translog production function through Stochastic Frontier Apoproach (SFA) was applied for estimating the efficiency of Boro production. Data were collected from biogas users in the four district of Bangladesh: Mymensingh, Pabna, Thakurgaon and Dinajpur. Biogas users have received significant impact from bio-slurry to Boro rice production while chemical fertilizers have no significant impact to same production. The production efficiency of biogas users is notably different from traditional farms. The efficiency differences are explained mostly by farm size, year of education, family size and off-farm income. Bio-slurry could be applied for reducing application of chemical fertilizers, pesticides and labour requirement that lead to more organic agriculture practices with producing more output, earn more income and save foreign currency.
\end{abstract}

Keywords: Bio-slurry, Technical Efficiency, Profitability, Boro

\section{Introduction}

The traditional cultivation procedure ultimately leads to create different environmental difficulties and challenges like, Bangladesh facing the problems on soil erosion, soil acidity, imbalance of nutrients in the soil, biodiversity and overall environmental degradation, however one can recognize, it is ultimate result of Green Revolution (Mendoza, 2002). Muller, et al., (2012) found that agriculture sector is responsible for $20-30 \%$ of global greenhouse gas emissions. This conventional method of growing rice is using chemical fertilizers, pesticides, irrigation and herbicides, etc. Continuation for its high yields, this production system demonstrated to enhance the above problems. Depletion of organic matter is often an important factor in the process of soil fertility decline. Healthy soil should have an organic matter content of more than $2.5 \%$ (BARC, 2005). Most soil in Bangladesh has less than 1.7\% and in some areas the soil has less than $1 \%$. Depletion of soil and declines in crop yields are observed everywhere in Bangladesh. If proper fertility management is not adopted, farmers more commonly use chemical fertilizers without adequate information on soil requirements (Von Nes et al., 2005). Ultimate studies have examined that overapplication of some nutrients and under-application of others have led to decrease production efficiency conclusions (Islam, 2006). It is already intensified the farm household's real and burden on high-cash capital expenses (Mendoza, 2003) as well in Bangladesh, rice farming is treated as a non-profit business for rural areas (Sarker and Itohara, 2008). Thus, prompt farmers are looking for alternative cultivation approach where could have facilities to minimize the environmental degradation, in addition to profitable business. In contrast to this, organic farming could be an alternative for right choice for farmers who have adopted as an alternative highly profitable farming enterprise compare to the conventional farming (FiBL, 2004; Rubinos et al., 2007).

Although, this study is not directly considered the impact of organic farming on agricultural production, however, the study is concentrated on slurry (treated as a core part of organic practice) implication on agricultural practices in Bangladesh. 


\section{Materials and Methods}

\section{Sampling procedures and methods of data collection}

The research has been conducted on the basis of slurry based semi-organic practice and conventional agricultural practice in the study. Indeed, the farm household doesn't rely completely only slurry practice in agricultural production though has applied slurry with least amount of chemical fertilizers. The purposive random sampling technique was used to carryout samples of biogas users (households already using the biogas plants). Primary data related to the households' socio-demographic and economic characteristics, including the motivation of using biogas plants were collected from 150 biogas user households. Data were analyzed by using statistical techniques (descriptive statistic, cross tabulation, frequency tables, means t- test, and Translog production function). The approach was used for estimating the efficiency level of Boro rice production with assistance of FRONTIER 4.1 software.

\section{Model specification}

A single output based multiple input frontier production approach has used to specify the production structure of rice farmers in Bangladesh. For this study, only Boro rice season is considered for analyzing due to it is the most contributory agricultural rice to national economy and having good memorized the using input data.

Translog frontier model is applied for analyzing on biogas user frontier model. Slurry is treated as continuous variable for biogas user model due to often practice the slurry to the rice field. For the pesticide use, often farmers are used the pesticide for rescued from pest attack. While few biogas users have not used the pesticide, thus, pesticide is applied as dummy variable.

The general form of the Translog stochastic production frontier for the $\mathrm{i}^{\text {th }}$ farm for Biogas users is defined as:

$\operatorname{lny}_{i}=\alpha_{0}+\sum_{j=1}^{7} \alpha_{j} \ln x_{i j}+\frac{1}{2} \sum_{j=1}^{7} \sum_{k=1}^{7} \beta_{j k} \ln x_{i j k} \ln x_{i j k}+T_{p t} P E S T+v_{i}-u_{i}$

Where the dependent variable $y_{i}$ is the quantity of total rice production (kg per farm), $x^{i}$ are the different production inputs: PEST is the dummy of pesticide variables. The input variables used in this pooled and biogas Translog production frontier: quantity of seed (kg per farm), quantity of slurry (kgper farm), quantity of chemical fertilizers ( $\mathrm{kg}$ per farm), quantity of labor (man-days per farm), cost of land preparation and different equipment used (BDT per farm), quantity of land (acre per farm) and cost of irrigation (BDT per farm). The random error variables $v_{i}$ and $u_{i}$ are defined above.

All the input variables in both models are mean-corrected $\left(x_{i k}-\bar{x}_{k}\right)$ prior to estimation. This has done so that the coefficients of the first order terms can be treated directly as elasticity's.

The model for the technical inefficiency for both the seasons can be defined as:

$u_{i}=\delta_{0}+\sum_{d=1}^{5} \delta_{d} z_{i j}+\omega_{i}$

Here the socio-economic characteristics of the farm to explain inefficiency are presented by $Z_{i}$. The socio-economic variables included in the model are: year of education level of household heads, off farm income (BDT) of a household, age of the household head, farm size per farm in acre and family size per farm. The random variable $\omega_{i}$ is the unobservable random error assumed to be independently distributed with a positive, half normal distribution. 


\section{Results and Discussion}

\section{Descriptive statistics of the variables of translog production function and technical efficiency effect model of Boro production}

The summary description of variables used in the translog production model and technical inefficiency model are presented in the Table 1 and Table 2, respectively. Table 1 presents the input use and it's produced output of Boro production of biogas users.

Table 1 shows biogas users are cultivated 2.53 ton per acre, respectively. While, BBS (2011) shows that the average production of HYV of Boro rice per acre produced in Bangladesh was 1.9 ton whichwas far behind from the average production of biogas users. The reasons behind for this difference of national average and finding mean of Boro rice production are to have the differences of off-farm income, education between national and biogas user households and finally, the biogas user applied the slurry for producing more production as well as maintaining the soil fertility.

The average land size is one acre of the biogas users. Usually, a traditional farmer employs more labor to produce certain level of Boro production due to often having more weeds problem. Biogas user is also aware to use the seed for planting. Land preparation cost is meant of power tiller use or cost of animal draft that part is a part and parcel for land preparation of Boro plantation.

Table 1. Summary statistics of the Boro production function (per acre)

\begin{tabular}{|l|c|}
\hline Variables & Biogas user \\
\hline Land (decimal) & 100 \\
\hline Labor (man-days) & $46.8(22.02)$ \\
\hline Seed (kg) & $24.15(9.77)$ \\
\hline Chemical Fertilizer (kg) & $74.07(40.375)$ \\
\hline Irrigation (000 BDT) & $3.75(0.8)$ \\
\hline Land prep. (BDT) & $1602(432.5)$ \\
\hline Slurry per year (ton) & $64.87(6.17)$ \\
\hline Farmers using pesticide (\%) & 92 \\
\hline Rice production (ton) & $2.53(0.80)$ \\
\hline
\end{tabular}

Note: Figures in the parentheses indicate standard deviations

Considering the whole summary statistics of Boro production, biogas users apply the inputs more rationally contrast to a general producer.

Table 2 shows that the biogas users are often learned more year of general schooling about 10 years. The average rate of year of education is far better than the national average (BBS, 2011). This significant difference made them efficiently using the inputs for agricultural production.

Agriculture is the major source of income however people want secured life by participating into off-farm income activities. The study found that farm households often cultivating their own land for agricultural production. Table 2 shows that biogas users are practiced more farm size agricultural land by 3.56 acre and family is more than the average size of Bangladesh.

Table 2. Descriptive statistics of the variable used in the technical efficiency model

\begin{tabular}{|l|c|}
\hline Variables & Biogas user \\
\hline Education (year) & $10.06(4.48)$ \\
\hline Age (year) & $41.71(11.07)$ \\
\hline Off-farm income (0000 BDT) & $14.72(13.72)$ \\
\hline Farm size (Acre) & $3.56(3.73)$ \\
\hline Family size (No.) & $5.37(2.30)$ \\
\hline
\end{tabular}

Note: Figures in the parentheses indicate standard deviations 


\section{Parameter estimates of the stochastic production frontier}

The following inputs in Table 3 stated that Boro production which have actually indispensable items for it's production. Naturally few of independent variables have more important or few of them have less contributory but accumulation of these inputs create the force to plant growth otherwise normal production should be hampered.

Among all the production inputs used in rice production, the effect of land is most dominancy player of Boro rice production. The estimated output elasticity of land for a biogas-user is 0.43 , it means $1 \%$ increase in land areas will result in $43 \%$ increase in rice production. The previous research also observed the rice elasticity of land is much higher than the labor and capital in the context of Asian countries. The differences of value of elasticity of land and others value are notably identified (Bardhan, 1973; Cornia, 1985). Some other studies also similarly stated that land has a significant impact of farm production in Bangladesh (Battesi and Broca, 1997; Wadud and White, 2000; Rahman, 2003).

The elasticity of labor found to have significant where labor is significant at $1 \%$. It may state that labor is also scarce resource especially in the peak period of Boro rice where price is normally hiked due shortage of agricultural labor supply. Seed is being less significant impact on Boro production.

The major attempt of this research is to find the impact of chemical fertilizers and slurry on the Boro production in Bangladesh. Table 3 presents that chemical fertilizers have no significant impact on biogas user households for Boro production and the co-efficient value also is negative, but for a traditional household have significant influence of chemical fertilizers for Boro production. It could be interpreted that a general household is totally concern and dependent on chemical fertilizers practice not to use of bioslurry. The related previous studies found that chemical fertilizers have strong significantly relationship with the efficiency of Boro rice production in Bangladesh (Anik, 2012; Miah et al. 2010; Rahman, 2003; Rahman, 2002).

Irrigation in Bangladesh is often meant of ground water that is used for Boro production. It is also indispensable input for dry season in Bangladesh whenever surface water is rarely available for its production. Land preparation and equipment cost also lead to significantly impact on Boro production for all sample households. Slurry also significantly influence to Boro production at $5 \%$ level of significance for biogas user.

Pesticide also directs another explanation where it has insignificant for biogas user. The previous findings (Anik, 2012; Miah, et al. 2010; Rahman, 2003; Rahman, 2002) found a general houshold is more concentrated to overuse the chemical fertilizers and less important to the land preparing, its' causes of more pesticide attack to the plants which negatively affect to total production as well as increase the total cost, degrade the soil fertility. Besides, biogas user household is often practiced the bio-slurry that seems to be an organic agriculture practicing that leads to use less amount of chemical fertilizers, need to less labor use, improve soil fertility, less practice of pesticides, etc.

\section{Interactions impact of biogas user}

The following couple of interactions of inputs have whether negative or positive significant influence to Boro production. Landxland interaction shows that it's played a vital role with statistically significant where Boro production could have extended further by more and more land practice. Another interaction of seed $x$ seed is negatively significant, it means that over use of seed is reduced the total production where a plant would not get healthier space for its growing. The co-efficient of square of land preparation and equipment explains that land is already good prepared for production, so it does need to further take care for its' production. Slurryxslurry of biogas users also has negative significant impact on Boro rice production. It means that the land already absorbed from sufficient use of slurry, however, using another pot of slurry will lead to reduction of total Boro rice production. Thus, over use of slurry is observed to decrease the total production.

The positive sign of interaction of landxseed implies that increasing the use of two inputs could increase the total production. If land is extended, it needs more seed that will impact of more Boro production. This explanation is similar for case of land xirrigation; labor×seed; irrigation $\times$ land preparation. On the other hand, the negative sign of interaction between labor and irrigation states that increasing one requires the reduction of another to increase output, ceteris paribus. 
Table 3. Maximum likelihood estimates for parameters of translog stochastic production function and technical inefficiency effect model

\begin{tabular}{|c|c|c|}
\hline Variables & Coeff. & SE \\
\hline Constant & $75.93^{\star \star *}$ & 0.97 \\
\hline Land (dec) & $0.43^{* * *}$ & 0.22 \\
\hline Labor (man-days) & $0.25^{\star *}$ & 0.11 \\
\hline Seed $(\mathrm{kg})$ & $0.04^{* * *}$ & 0.01 \\
\hline Che. Fert. (kg) & -0.07 & 0.84 \\
\hline Irrigation (BDT) & $-0.19^{* *}$ & 0.07 \\
\hline Land Prepar. and equipment(BDT) & $0.29^{* \star *}$ & 0.08 \\
\hline Slurry & $0.20^{\star *}$ & 0.10 \\
\hline Pesticide & -0.01 & 0.01 \\
\hline Land $\times$ Land & $0.59^{\star \star \star}$ & 0.04 \\
\hline Labor $\times$ Labor & 0.09 & 0.08 \\
\hline Seed $\times$ Seed & $-0.26^{* * *}$ & 0.85 \\
\hline Che. Fert $\times$ Che. Fert & 0.11 & 0.04 \\
\hline Irrigation $\times$ Irrigation & -0.59 & .48 \\
\hline Preparat. $\times$ Preparat. & $-0.28^{* *}$ & 0.13 \\
\hline Slurry $\times$ slurry & $-0.04^{* * *}$ & 0.01 \\
\hline Land $\times$ Labor & -0.58 & 0.67 \\
\hline Land $\times$ Seed & $0.12^{*}$ & 0.07 \\
\hline Land $\times$ Che. Fert & 0.04 & 0.36 \\
\hline Land $\times$ Irrigation & $0.16^{*}$ & 0.09 \\
\hline Landx Preparat. & 0.58 & 0.86 \\
\hline Land $\times$ Slurry & -0.88 & 0.53 \\
\hline Labor $\times$ Seed & $0.11^{* \star \star}$ & 0.03 \\
\hline Labor $\times$ Che. Fert & 0.05 & 0.23 \\
\hline Laborx Irrigation & $-0.12^{*}$ & 0.061 \\
\hline Laborx Preparat. & 0.63 & 0.42 \\
\hline Labor $\times$ Slurry & 0.02 & 0.29 \\
\hline Seed $\times$ Che. Fert. & 0.27 & 0.20 \\
\hline Seed $\times$ Irrigation & -0.48 & 0.68 \\
\hline Seed $\times$ Preparat & $-0.78^{*}$ & .41 \\
\hline Seed $\times$ Slurry & 0.32 & 0.37 \\
\hline Che. Fert× Irrigation & 0.18 & 0.36 \\
\hline Che. Fert $\times$ Preparat. & -0.34 & 0.27 \\
\hline Che. Fert $\times$ Slurry & $0.30^{*}$ & 0.16 \\
\hline Irrigation $\times$ Preparat. & $0.13^{\star *}$ & 0.06 \\
\hline Irrigation $\times$ Slurry & $-0.16^{* *}$ & 0.05 \\
\hline Preparat. $\times$ Slurry & -0.33 & 0.35 \\
\hline Tech & ictors & \\
\hline Constant & $0.37^{* *}$ & 0.18 \\
\hline Farm size (Acre) & $-0.02^{\star \star \star}$ & 0.01 \\
\hline Family size (No.) & -0.001 & 0.02 \\
\hline family head education (year) & $-0.001^{*}$ & 0.00069 \\
\hline Age of family head (year) & 0.0016 & 0.003 \\
\hline Off-farm income (0000.BDT) & $-0.002^{\star \star}$ & 0.001 \\
\hline$\sigma^{2}=\sigma_{u}^{2}+\sigma_{v}^{2}$ & $0.016^{* \star *}$ & \\
\hline$\gamma=\sigma_{u}^{2} /\left(\sigma_{u}^{2}+\sigma_{v}^{2}\right)$ & 0.097 & 0.36 \\
\hline Log likelihood function & \multicolumn{2}{|c|}{60.49} \\
\hline Total number of observation & \multicolumn{2}{|c|}{91} \\
\hline
\end{tabular}

Note: All input variables are mean - differenced prior to estimation, and therefore the coefficients on the first order term can be read directly as elasticity at the sample mean, and *,**, and ${ }^{* * *}$ indicate significance levels at $10 \%, 5 \%$, and $1 \%$, respectively. 


\section{Determinants of technical inefficiency}

Lower section of Table 3 presented the results of technical inefficiency effect model for biogas usersand biogas non-users. It has been found that only farm size has a significant effect to the inefficiency for biogas users. Among other inefficiency variables, year of family head's education and off-farm income are played significant role to increase farm inefficiency.

The farm size is significant at $1 \%$ level and the coefficient value is negative implies that households are becoming more efficient with increasing the farm size or increasing the farm size leads to reduce the inefficiency of farm production. Farm size means of actual land which household is directly cultivated for farm's production. The sign is expected as earlier research mentioned similar result. Rahman (2002) found the same direction of farm size to efficiency of rice production in Bangladesh. Other previous researches also found the share of own land impact to efficiency, where owner are found to operate higher level of efficiency compare to the tenant (Anik, 2012; Miah et al. 2010; Rahman, 2003).

The coefficient of family size is failed to show the expected direction of sign and significant level of biogas user household.

The year of family head education and efficiency of Boro rice production have a significant relationship with biogas user. The result implies that increasing the education reduces the inefficiency for biogas user group. Rahman (2002) also found same negative sign of coefficient of education in relation to production inefficiency in Bangladesh, besides Anik (2012) did not find anymore significant relation with education and efficiency of rice production. Certainly, Deb (1995) mentioned that as cited in Coelli et al.,( 2002) such uncorrelated result might be the relation of lower level schooling which in their specific case is less than four years. In this study, the average year of education of family head is 10.06 level (Table 2). In Bangladesh, students normally learn the general education up to eight years. Therefore, Above eight class could have showed significant positive impact on efficiency with this type of general education. However, with this situation people have been learning more from day to day practice.

The biogas user household is negative related to inefficiency with $5 \%$ level of significantce. The result explains that increasing the off-farm income is given more attention to the Boro rice production by Biogas users that lead to decreasing inefficiency. Biogas user group noticed where having more household income level per year compared to the national average. While, biogas user household wants to ensure their food security at first and then giving remaining time for non-farm activities.

\section{Technical efficiency in Boro rice production}

The summary statistics of technical efficiency of Boro rice production are presented in Table 5. The mean technical efficiency score for biogas user is 0.91 . The mean technical efficiency of other previous studies also found the high level efficiency of Boro rice production in Bangladesh. Balcombe et al., (2007) also clearly explained that modern variety producers operated at high level of technical efficiency. Miah et al., (2010) stated that the efficiency of Boro rice production in Bangladesh are $84.6 \%$ and $88.0 \%$ which are quite similar result of this study. Thus, biogas users practiced Boro rice production efficiently compares to the traditional farmers.

Table 5 shows four categories of ranges of efficiency including range of up to $70 \%, 70-80 \%, 80-90 \%$ and above $90 \%$. About $69 \%$ of total biogas users is found to be range of more than $90 \%$ group whereas only about $2 \%$ are in below $70 \%$ range. This results show the notion of this study, it means biogas users practiced the rice production efficiently. 
Table 5. Technical efficiency in Boro rice production

\begin{tabular}{|l|c|}
\hline Efficiency level & Biogas users \\
\hline Up to $70 \%$ & 2.20 \\
\hline $70-80 \%$ & 12.09 \\
\hline $80-90 \%$ & 16.48 \\
\hline $90 \%$ and above & 69.23 \\
\hline Efficiency Score & 0.91 \\
\hline Mean (\%) & 0.01 \\
\hline SE & 0.62 \\
\hline Min (\%) & 0.98 \\
\hline Max (\%) & \\
\hline
\end{tabular}

Source: Author's calculation (2013)

\section{Conclusion}

The main objective of this chapter is to analyze the impact of slurry and chemical fertilizers to the farm efficiency by biogas user. It found the impact of slurry variables to have impact on farm technical efficiency. Slurry has a positive significant relationship with biogas user by which households can have increase the total output. That implies overall impact of slurry have found on total Boro production increasing due to increase soil fertility, with less chemical fertilizers and labor use, as well as reduce $\mathrm{CO} 2$ emission, reducing the use of dry dung cake etc. But, chemical fertilizers have no more significant relation with biogas user. It found from previous studies that a traditional farmer is devoted to use more chemical fertilizers for producing more output, still households are behind from information of advantages of slurry use. The explanation for this case is to reduce the fertilizer use and increase the slurry use that make it more production and sustainable growth to the nation as well farm efficiency would be growing up. The stochastic production frontier examined households have potentiality to produce more with improvement of efficiency. Land is the most vital component for increasing Boro production. Labor has credibility to produce more output but need to take care of proper utilization. Irrigation is oxygen for Boro production in Bangladesh. It is one other most core inputs using for Boro rice production in winter season of Bangladesh. $v$ Influences from other variables are found to be group specific. Farm size is one of the core inputs for reduce the inefficiency level for all groups. Compare to mean efficiency of biogas users and other traditional practioners, biogas user is notably superior performing.

Thus, slurry can be played a significant role to reduce the practice of chemical fertilizers, save the significant amount of foreign currencies, less labor required due to low weed protection, low amount pesticide use, less $\mathrm{CO}_{2}$ emission, creat a sustainable agricultural crops practices.

\section{References}

Anik, A.R. 2012. Farm Level Corruption and Its Impact on Farm Production and Food Security in Bangladesh, Doctoral Thesis Submitted to the JLU Giessen, Margraf Publishers, pp 105.

Balcombe, K.I., Fraser, I., Rahman, M. and Smith, L. 2007. Examining the Technical Efficiency of Rice Producers in Bangladesh. Journal of International Development, 19(1):1-16.

BARC. 2005. Fertilizer Recommendation Guide. Bangladesh Agricultural Research Council, Farmgate, Dhaka-1215, 260 p.

Bardhan, P.K. 1973. Size, Productivity and Returns to Scale: An Analysis of Farm Level Data in Indian Agriculture. Journal of political economy 81(6): 1370-1386.

Battesi, G.E. and Broca, S.S.1997. Functional Forms of Stochastic Frontier Production Functions and Models for Technical Inefficiency Effects: A Comparative Study for Wheat Farmers in Pakistan. Journal of Productivity Analysis, 8(4): 395-414.

BBS. 2011. Bangladesh Bureau of Statistics. 2011. Ministry of Planning, GOB, Dhaka

Coelli, T.J., Rahman, S., and Thirtle, C. 2002. Technical, Allocative, Cost and Scale Efficiencies in Bangladesh Rice Cultivation: A Non-parametric Approach. Journal of Agricultural Economics, 53 (3): 607-626.

Cornia, G.A. 1985. Farm Size, Land Yields and Agricultural Production Function: An Analysis For for Fifteen Developing Countries. World Development, 13(4):513-534. 
Deb, U.K. 1995. Human Capital and Agricultural Growth in Bangladesh, Unpublished PhD Thesis, University of the Philippines, Los Banos.

FiBL. 2004. Organic Farming in Italy 2004. A Country Report of Organic Europe, available at: http://www.organiceurope.net/country_reports/italy/default.asp (accessed Nov. 5, 2006).

Islam, M.S. 2006. Use of Bioslurry as Organic Fertilizer in Bangladesh Agriculture. Paper Presented in the International Workshop, Bangkok, Thailand, 27-28 September 2006.

Mendoza, T. 2002. Impact Analysis of Organic Farming in Rice Agro-Ecosystems in the Philippines. First RDA/ARNOA International Conference, RDA and Dankook University of Korea, November 12-15, 2002.

Mendoza, T. 2003. "Upscaling the Adoption of Ecologically Sound Agriculture in The Philippines. Retrieved August 2, 2006 available from http://www.rosneath.com.au/ipc6/ch06/mendoza/index.html.

Miah, M.I.A., Abedin M.Z., and Rahman, K.M.M. 2010. Farm Level Availability of Rice and It's Losses: An Assessment Study For Food Policy Options, Report submitted to National Food Policy Capacity Strengthening Programme, GOB, Dhaka. http://www.nfpcsp.org/agridrupal/sites/default/files/ldris_Ali_Mia-PR2-08.pdf (Accessed by 20 January, 2012).

Muller A., Olesen, J., Smith, L., Davis, J., Dytrtová, K., Gattinger, A., Lampkin, N., and Niggli, U. 2012. Reducing Global Warming and Adapting to Climate Change: The Potential Of Organic Agriculture. Working Paper in ECONOMICS, University of Gothenburg. http://gupea.ub.gu.se/dspace/bitstream/2077/29131/1/gupea_2077_29131_1.pdf (Accessed by 2 May 2012).

Rahman, K.M.M. 2002. Measuring Efficiency of Producing Rice in Bangladesh: A Stochastic Frontier Analysis. Wissenschaftsverlag vauk kiel KG.

Rahman, S. 2003. Profit Efficiency among Bangladeshi Rice Farmers. Food Policy, 28(5-6): 487-503.

Rubinos, R., Jalipa, A.T., and Bayacag, P. 2007. Comparative Economic Study of Organic and Conventional Rice Farming In Magsaysay, Davao Del Sur. Paper Presented in $10^{\text {th }}$ National Convention on Statistics (NCS), October 1-2, 2007, EDSA Shangri-La Hotel, Plillippines.

Sarker, M. A. and Itohara, Y. 2008. Organic Farming and Poverty Elimination: A Suggested Model for Bangladesh. Journal of Organic Systems. 3(1): 68-79.

Von Nes,W.J., Boers, W., and Islam, K. 2005. Feasibility of A National Programme on Domestic Biogas in Bangladesh. Submitted the Final Paper to the Netherlands Development Organization, Hague, Netherlands.

Wadud, A. and White, B. 2000. Farm Household Efficiency in Bangladesh: A Comparison of Stochastic Frontier and Dea Models, Applied Economics, 32: 1665-73. 